Ocular Oncology

and Pathology
Ocul Oncol Pathol 2016;2:246-250

DOI: $10.1159 / 000447063$
Received: April 26, 2016

Accepted after revision: May 24, 2016

Published online: July 1, 2016

\title{
Cat Scratch Disease: Expanded Spectrum
}

\author{
Hassan A. Aziz ${ }^{a}$ Thomas P. Plesec ${ }^{b}$ Camille Sabellac Unni K. Udayasankar ${ }^{d}$ \\ Arun D. Singh ${ }^{\mathrm{a}}$ \\ ${ }^{\mathrm{a}}$ Department of Ophthalmology, Cole Eye Institute, and Departments of ${ }^{\mathrm{b}}$ Anatomic Pathology, ${ }^{\mathrm{c} P e d i a t r i c}$ Infectious \\ Diseases and ${ }^{\mathrm{d}}$ Radiology, Cleveland Clinic Foundation, Cleveland, Ohio, USA
}

\section{Key Words}

Cat scratch disease $\cdot$ Histopathology - Optic nerve granuloma $\cdot$ Pineal gland $\cdot$ Bartonella $\cdot$ Peripapillary

angiomatous lesion $\cdot$ Retinoblastoma

\section{Abstract}

Background: To expand the spectrum of ophthalmic manifestations in cat scratch disease. Methods: Case report. Results: A 7-year-old male was referred for evaluation of his left optic disc after failing vision screening test at school. His visual acuity was 20/20 OD and light perception OS. Fundus examination showed a left optic disc lesion associated with an exudative retinal detachment and vitreous seeding. Ultrasonography revealed a $7 \times 7.5 \times 3.8 \mathrm{~mm}$ lesion with a possible $6.3 \mathrm{~mm}$ of retrolaminar extension into the substance of the optic nerve. Brain MRI did not show evidence of optic nerve involvement but revealed a 6-mm nodule of the pineal gland suggestive of a pineoblastoma. Enucleation was performed and histopathology revealed a suppurative granulomatous inflammation suggestive of Bartonella infection. Upon further questioning, the patient had recent exposure to kittens with areas of cat scratches along both of his arms. He was subsequently referred to and treated with a 2-week course of trimethoprim-sulfamethoxazole and rifampin by the pediatric infectious disease specialist. Repeat brain MRI showed interval total resolution of enlarged pineal gland. Conclusion: Optic nerve granulomas are a rare presentation of cat scratch disease and could potentially masquerade as retinoblastoma.

(c) 2016 S. Karger AG, Basel

\section{Case Report}

A 7-year-old male without past medical or past family history was referred to the Ocular Oncology service at the Cole Eye Institute for evaluation of a left optic disc lesion after failing a vision screening test at school. His visual acuity was $20 / 20$ in the right eye and light perception in the left eye. Ophthalmic examination was significant for a vascular mass arising from his left optic disc measuring $7 \mathrm{~mm}$ with associated fine intrinsic vasculature, surrounding torturous retinal vessels and scattered retinal hemorrhages. Inferior exudative retinal detachment was evident. Small white/tan vitreous and preretinal seeds were present throughout the inferior vitreous (fig. 1). His last eye examination 6 months prior to presentation was within normal limits.

Ultrasonography revealed a mass that measured $7 \times 7.5 \mathrm{~mm}$ in basal dimensions and $3.8 \mathrm{~mm}$ in height overlying the optic disc with possible posterior retrolaminar extension into the substance of the optic nerve. The retrolaminar portion measured $6.3 \mathrm{~mm}$ in depth. No calcification was detected within the lesion. Brain MRI revealed a $6-\mathrm{mm}$ enhancing mass within the left globe immedi-

\section{KARGER}

E-Mail karger@karger.com

www.karger.com/oop
(C) 2016 S. Karger AG, Basel

2296-4681/16/0024-0246\$39.50/0
Arun D. Singh, MD

Department of Ophthalmic Oncology Cole Eye Institute, Cleveland Clinic Foundation 2022 E 105th St, Cleveland, OH 44106 (USA)

E-Mail singha@ccf.org 
Fig. 1. a Colored fundus photo of the left eye reveals a vascular mass arising from the optic disc with associated fine intrinsic vasculature, surrounding torturous retinal vessels, scattered retinal hemorrhages and an inferior exudative retinal detachment extending into the macular area. b Higher magnification fundus photo highlighting the small white/tan vitreous and preretinal seeds present throughout the inferior vitreous.
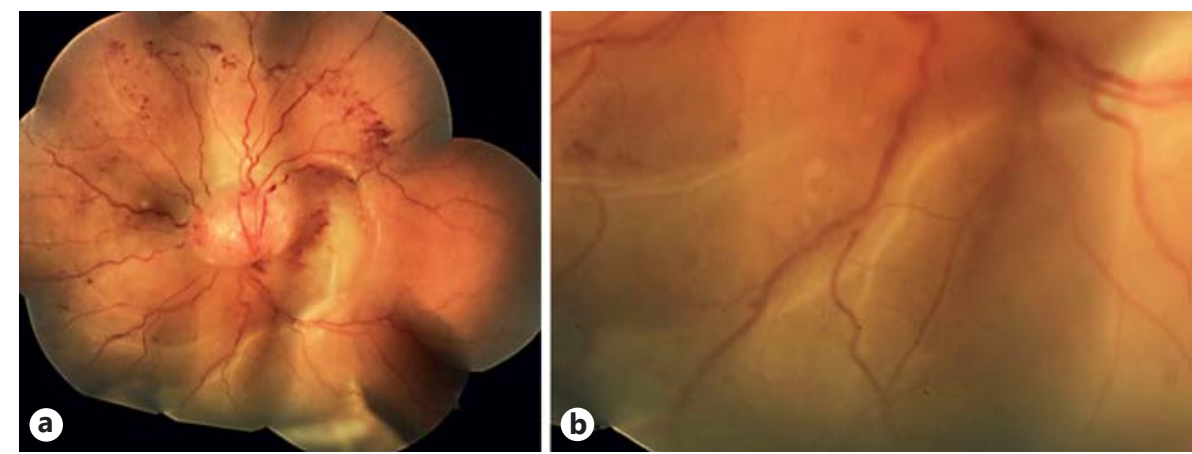

Fig. 2. a Axial and sagittal post contrast T1weighted images show a pineal region lesion with an enhancing eccentric nodule. b Follow-up images show interval resolution of the enhancing nodule.
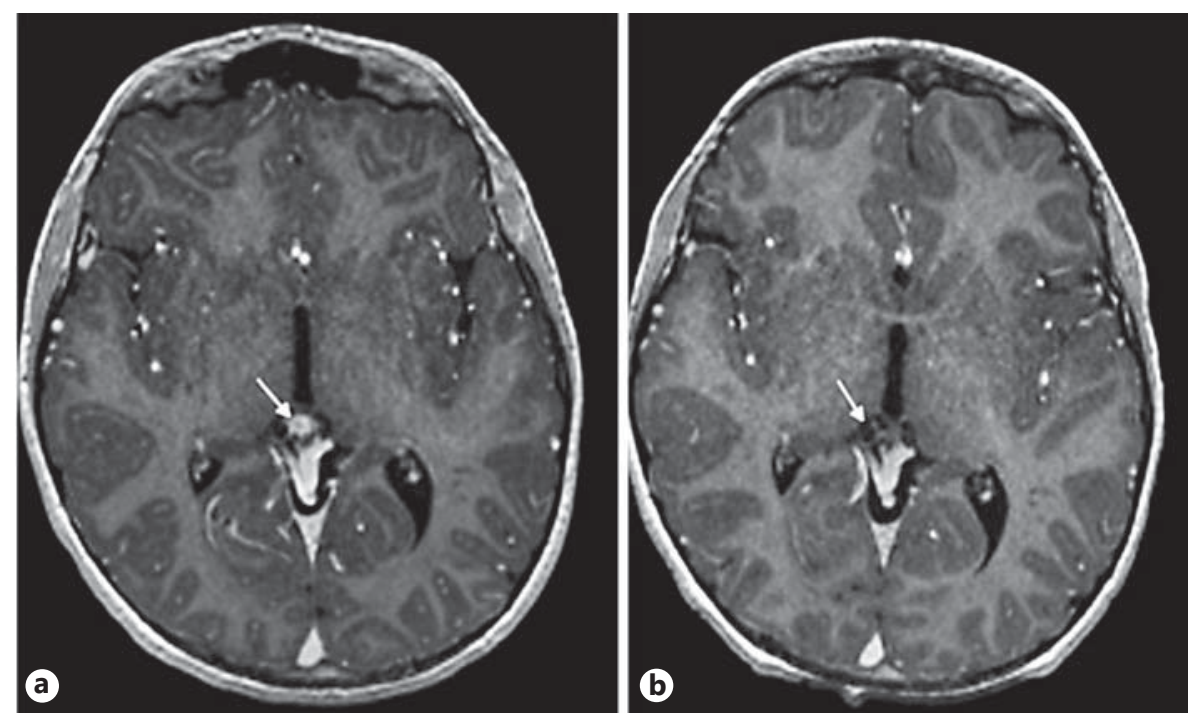

Fig. 3. a Hematoxylin and eosin-stained section $(\times 100)$ showing a necrotizing granulomatous inflammation involving the optic disc, nerve, and retina. b Hematoxylin and eosin-stained section $(\times 200)$ showing a higher magnification of the granulomatous inflammation with a histiocytic infiltrate and giant cells.
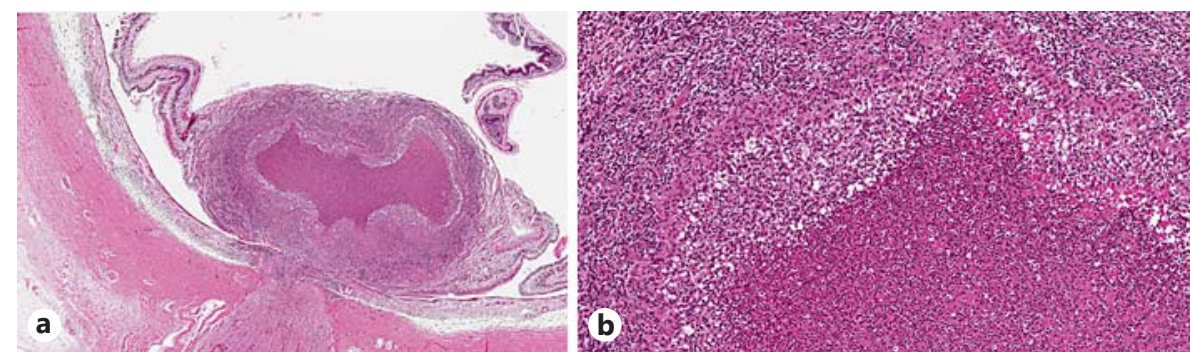

ately adjacent to the optic nerve insertion (fig. 2a). No definite posterior optic nerve extension was noted. Moreover, an eccentric 6-mm nodule of enhancement was noted within the pineal gland. Given the presence of the mass within the left globe and a pineal gland nodule findings were concerning for retinoblastoma with associated pineoblastoma (trilateral retinoblastoma).

Examination under anesthesia confirmed the findings of a left optic disc mass with vitreous seeding and a normal right eye. At that point, the differential diagnosis included: inflammatory or infectious granuloma, optic disc hemangioma, retinoblastoma, medulloepithelioma or an optic nerve tumor (e.g. glioma).

Retinoblastoma is the most common intraocular tumor in childhood. More than $95 \%$ of cases are diagnosed before the age of
5 years [1]. Patients carrying the $R B 1$ germline mutation have a risk of developing trilateral retinoblastoma - a combination of intraocular retinoblastoma and similar tumor involving the pineal gland [2]. Extraocular extension occurs mainly via the optic nerve potentially reaching the orbit and brain. Although retinoblastoma is unusual in our patient's age group especially in a posterior location, fine needle aspiration biopsy to further characterize the mass would be contraindicated because of concerns for conjunctival or orbital seeding. But given the findings of an optic disc lesion with vitreous seeding, possible postlaminar extension and pineal gland mass suggestive of pineoblastoma, the diagnosis of retinoblastoma could not be excluded. Current treatment recommendation for retinoblastoma with optic nerve extension is enucleation and pos- 
Table 1. A summary of clinical manifestations, treatment and outcomes of patients presenting with optic disc granulomas associated with CSD

\begin{tabular}{|c|c|c|c|c|c|c|}
\hline & $\begin{array}{l}\text { Age, years/ } \\
\text { gender }\end{array}$ & Initial VA & Pertinent exam findings & $\begin{array}{l}\text { Pertinent systemic workup and } \\
\text { findings }\end{array}$ & Treatment & Outcomes \\
\hline $\begin{array}{l}\text { Fish et al. } \\
(1992)[5]\end{array}$ & $22 / \mathrm{M}$ & $\begin{array}{l}\text { OD: LP } \\
\text { OS: } 20 / 20\end{array}$ & $\begin{array}{l}\text { OD: } 3+\text { AC cell, } 1+\text { vitreous cell, } \\
\text { peripapillary anigomatous lesion, optic } \\
\text { disc edema, and serous papillomacular } \\
\text { retinal detachment OS: two small, } \\
\text { white, intraretinal infiltrates }\end{array}$ & $\begin{array}{l}\text { Recent febrile illness, } \\
\text { lymphadenopathy and cat bite } \\
\text { Elevated Bartonella titers } \\
\text { Lymph node biopsy compatible } \\
\text { with CSD }\end{array}$ & $\begin{array}{l}1 \text { month of clindamycin } \\
\text { hydrochloride }\end{array}$ & $\begin{array}{l}\text { 1-month f/u: resolution } \\
\text { of serous retinal } \\
\text { detachment; VA 20/40 }\end{array}$ \\
\hline $\begin{array}{l}\text { Ulrich et al. } \\
\text { (1992) [6] }\end{array}$ & $6 / \mathrm{F}$ & $\begin{array}{l}\text { OD: CF } 2 \mathrm{ft} \\
\text { OS: } 20 / 25\end{array}$ & $\begin{array}{l}\text { OD: } 3+\text { AC cell, ON granuloma, a } \\
\text { large inflammatory mass of the ON } \\
\text { head with surrounding exudative } \\
\text { retinal detachment and hard } \\
\text { exudates }\end{array}$ & $\begin{array}{l}\text { Recent febrile illness and cat } \\
\text { scratches }\end{array}$ & $\begin{array}{l}12 \text { days of i.v. } \\
\text { dexamethasone and i.v. } \\
\text { TMP-SMX then discharged } \\
\text { on p.o. TMP-SMX and } \\
\text { prednisone taper for } 8 \text { weeks }\end{array}$ & $\begin{array}{l}\text { 7-month f/u: residual } \\
\text { gliosis and resolution of } \\
\text { disc swelling; VA 20/25 }\end{array}$ \\
\hline $\begin{array}{l}\text { Cunningham } \\
\text { et al. (1997) [7] }\end{array}$ & $7 / \mathrm{F}$ & $\begin{array}{l}\text { OD: } 20 / 20 \\
\text { OS: LP }\end{array}$ & $\begin{array}{l}\text { OD: small focus of retinitis } \\
\text { OS: AC and vitreous cell, a large } \\
\text { inflammatory mass of the ON head } \\
\text { with surrounding exudative RD and } \\
\text { hard exudates } \\
\text { Scattered intraretinal hemorrhages } \\
\text { and a small focus of retinitis }\end{array}$ & $\begin{array}{l}\text { Recent febrile illness and cat } \\
\text { scratches } \\
\text { Elevated Bartonella titers }\end{array}$ & 1 month of TMP-SMX & $\begin{array}{l}10 \text {-month } \mathrm{f} / \mathrm{u} \text { : } \\
\text { resolution of the } \\
\text { subretinal fluid and ON } \\
\text { head inflammation; VA } \\
20 / 50\end{array}$ \\
\hline $\begin{array}{l}\text { Cunningham } \\
\text { et al. (1997) [7] }\end{array}$ & $21 / \mathrm{F}$ & $\begin{array}{l}\text { OD: } 20 / 200 \\
\text { OS: } 20 / 20\end{array}$ & $\begin{array}{l}\text { OD: vitreous cell, large } \\
\text { inflammatory mass of the ON head } \\
\text { with subretinal fluid and a macular } \\
\text { star pattern of hard exudate } \\
\text { OS: within normal limits }\end{array}$ & $\begin{array}{l}\text { Recent febrile illness } \\
\text { Positive cat exposure }\end{array}$ & $\begin{array}{l}\text { Doxycycline (dose and } \\
\text { duration not specified) }\end{array}$ & $\begin{array}{l}\text { 1-month f/u: decreased } \\
\text { ON inflammation; VA } \\
20 / 60\end{array}$ \\
\hline $\begin{array}{l}\text { Kerrison } \\
\text { et al. (1999) [8] }\end{array}$ & $57 / \mathrm{F}$ & $\begin{array}{l}\text { OD: } 20 / 20 \\
\text { OS: } 20 / 400\end{array}$ & $\begin{array}{l}\text { OD: within normal limits } \\
\text { OS: } 2+\text { vitreous cell, a cystic dome- } \\
\text { shaped elevation overlying the left } \\
\text { ON with deep white retinal lesions, } \\
\text { macular star formation was evident } \\
\text { on f/u examinations }\end{array}$ & $\begin{array}{l}\text { Recent febrile illness and cat } \\
\text { scratches } \\
\text { Elevated Bartonella titers } \\
\text { Elevated erythrocyte } \\
\text { sedimentation rate }\end{array}$ & No treatment & $\begin{array}{l}\text { 6-week f/u: macular star } \\
\text { and deep retinal lesions } \\
\text { diminished; VA 20/25 }\end{array}$ \\
\hline $\begin{array}{l}\text { Gray et al. } \\
\text { (1999) [9] }\end{array}$ & $20 / \mathrm{M}$ & $\begin{array}{l}\text { OD: HM } \\
\text { OS: } 20 / 20\end{array}$ & $\begin{array}{l}\text { OD: AC and vitreous cell, vascular } \\
\text { mass involving the ON associated } \\
\text { with ischemic hemiretinal } \\
\text { whitening and a macular star } \\
\text { OS: within normal limits }\end{array}$ & $\begin{array}{l}\text { Recent febrile illness and cat } \\
\text { scratches } \\
\text { Elevated Bartonella titers }\end{array}$ & $\begin{array}{l}6 \text { weeks of doxycycline and } \\
\text { rifampin (did not respond } \\
\text { to } 7 \text {-day course of } \\
\text { clindamycin) }\end{array}$ & $\begin{array}{l}\text { 1-month f/u: replacement } \\
\text { of lesion with peripapillary } \\
\text { fibrotic tissue, resolution } \\
\text { of the ischemic retinal } \\
\text { whitening, persistent } \\
\text { remnants of a macular } \\
\text { star; VA 20/400 }\end{array}$ \\
\hline $\begin{array}{l}\text { Solley et al. } \\
\text { (1999) [10] }\end{array}$ & $21 / \mathrm{M}$ & $\begin{array}{l}\text { OD: } 20 / 400 \\
\text { OS: } 20 / 20\end{array}$ & $\begin{array}{l}\text { OD: trace vitreous cell, optic disc } \\
\text { granuloma, macular star, disc } \\
\text { edema and deep retinal white spots } \\
\text { OS: one deep retinal white spot }\end{array}$ & $\begin{array}{l}\text { Recent febrile illness and cat } \\
\text { scratches } \\
\text { Elevated Bartonella titers }\end{array}$ & $\begin{array}{l}\text { Vancomycin and } \\
\text { ceftazidime (dose and } \\
\text { duration not specified) }\end{array}$ & 3-month f/u: VA 20/60 \\
\hline $\begin{array}{l}\text { Solley et al. } \\
\text { (1999) [10] }\end{array}$ & $57 / \mathrm{F}$ & $\begin{array}{l}\text { OD: } 20 / 200 \\
\text { OS: not reported }\end{array}$ & $\begin{array}{l}\text { OD: } 2+\text { vitreous cell, vitreous } \\
\text { hemorrhage, optic disc granuloma, } \\
\text { disc edema, macular star and white } \\
\text { retinal lesions }\end{array}$ & $\begin{array}{l}\text { Recent febrile illness and cat } \\
\text { scratches } \\
\text { Elevated Bartonella titers }\end{array}$ & None & 3-month f/u: VA 20/25 \\
\hline $\begin{array}{l}\text { Solley et al. } \\
\text { (1999) [10] }\end{array}$ & $25 / \mathrm{F}$ & $\begin{array}{l}\text { OD: } 20 / 400 \\
\text { OS: } 20 / 20\end{array}$ & $\begin{array}{l}\text { OD: 1+ vitreous cell, optic disc } \\
\text { granuloma, macular star, disc } \\
\text { edema and choroidal lesions } \\
\text { OS: one deep retinal white spot }\end{array}$ & $\begin{array}{l}\text { 5-week history of headaches } \\
\text { Recent cat scratches }\end{array}$ & $\begin{array}{l}3 \text { weeks of ciprofloxacin } \\
\text { and } 2 \text { weeks of low-dose } \\
\text { prednisone taper }\end{array}$ & 1-month f/u: VA 20/200 \\
\hline $\begin{array}{l}\text { Matsuo } \\
\text { et al. }(2000)[11]\end{array}$ & $18 / \mathrm{F}$ & $\begin{array}{l}\text { OD: N/A } \\
\text { OS: CF }\end{array}$ & $\begin{array}{l}\text { OD: N/A } \\
\text { OS: vitreous cell, optic disc } \\
\text { granuloma, macular star, white } \\
\text { retinal infiltrates }\end{array}$ & Recent cat scratches & $\begin{array}{l}1 \text { month of TMP-SMX, } \\
\text { high-dose prednisone taper }\end{array}$ & 1-month f/u: VA 20/20 \\
\hline $\begin{array}{l}\text { Matsuo } \\
\text { et al. (2000) [11] }\end{array}$ & $51 / \mathrm{F}$ & $\begin{array}{l}\text { OD: N/A } \\
\text { OS: } 2 / 100\end{array}$ & $\begin{array}{l}\text { OD: N/A } \\
\text { OS: AC and vitreous cell, optic disc } \\
\text { granuloma, macular star, branch } \\
\text { retinal vein occlusion }\end{array}$ & $\begin{array}{l}\text { Recent febrile illness and cat } \\
\text { scratches }\end{array}$ & $\begin{array}{l}1 \text { month of TMP-SMX, } \\
\text { low-dose prednisone taper }\end{array}$ & 1-month f/u: VA 20/25 \\
\hline $\begin{array}{l}\text { Matsuo } \\
\text { et al. }(2000) \text { [11] }\end{array}$ & $11 / \mathrm{M}$ & $\begin{array}{l}\text { OD: N/A } \\
\text { OS: } 3 / 100\end{array}$ & $\begin{array}{l}\text { OD: N/A } \\
\text { OS: vitreous cell, optic disc } \\
\text { granuloma, macular star }\end{array}$ & $\begin{array}{l}\text { Recent febrile illness and cat } \\
\text { scratches }\end{array}$ & $\begin{array}{l}1 \text { month of TMP-SMX, } \\
\text { low-dose prednisone taper }\end{array}$ & 1-month f/u: VA 20/30 \\
\hline $\begin{array}{l}\text { Curi et al. } \\
(2010)[4]\end{array}$ & $12 / \mathrm{M}$ & $\begin{array}{l}\text { OD: CF } \\
\text { OS: } 20 / 20\end{array}$ & $\begin{array}{l}\text { OD: optic disc granuloma } \\
\text { OS: within normal limits }\end{array}$ & $\begin{array}{l}\text { Recent cat scratches } \\
\text { Elevated Bartonella titers }\end{array}$ & $\begin{array}{l}\text { Doxycycline duration and } \\
\text { dose not specified }\end{array}$ & $\begin{array}{l}\text { Duration of f/u not } \\
\text { specified: VA } 20 / 160\end{array}$ \\
\hline $\begin{array}{l}\text { Curi et al. } \\
(2010)[4]\end{array}$ & $26 / \mathrm{M}$ & $\begin{array}{l}\text { OD: LP } \\
\text { OS: } 20 / 20\end{array}$ & $\begin{array}{l}\text { OD: optic disc granuloma } \\
\text { OS: retinal infiltrate }\end{array}$ & $\begin{array}{l}\text { Recent febrile illness and cat } \\
\text { scratches } \\
\text { Elevated Bartonella titers }\end{array}$ & $\begin{array}{l}\text { Doxycycline duration and } \\
\text { dose not specified }\end{array}$ & $\begin{array}{l}\text { Duration of f/u not } \\
\text { specified: VA 20/200 }\end{array}$ \\
\hline $\begin{array}{l}\text { Ghazi and Sams } \\
\text { (2012) [12] }\end{array}$ & $12 / \mathrm{M}$ & $\begin{array}{l}\text { OD: } 2 / 400 \\
\text { OS: } 20 / 20\end{array}$ & $\begin{array}{l}\text { OD: optic disc granuloma, macular } \\
\text { star, plaque choroiditis and an } \\
\text { associated serous retinal } \\
\text { detachment. Retinal artery-to-vein } \\
\text { anastomosis present peripherally } \\
\text { OS: sectoral hyperemia of the ON } \\
\text { with a focal area of chorioretinitis }\end{array}$ & $\begin{array}{l}\text { Recent febrile illness and cat } \\
\text { scratches } \\
\text { Elevated Bartonella titers }\end{array}$ & $\begin{array}{l}\text { Doxycycline } 100 \mathrm{mg} \text { twice } \\
\text { a day and low-dose } \\
\text { prednisone taper }\end{array}$ & $\begin{array}{l}\text { 6-week f/u: regression of } \\
\text { posterior segment } \\
\text { lesions with persistent } \\
\text { subretinal hard exudates } \\
\text { and macular striae; VA } \\
\text { 20/80 }\end{array}$ \\
\hline
\end{tabular}

$\mathrm{AC}=$ Anterior chamber; $\mathrm{CF}=$ counting fingers; $\mathrm{f} / \mathrm{u}=$ follow-up $\mathrm{HM}=$ hand motion; $\mathrm{LP}=$ light perception; $\mathrm{N} / \mathrm{A}=$ not available; $\mathrm{ON}=$ optic nerve; $\mathrm{TMP}-\mathrm{SMX}=$ trimethoprimsulfamethoxazole; VA = visual acuity. 
sible adjuvant chemotherapy. After a long discussion with the parents, they agreed with our recommendation of proceeding with enucleation of the involved eye with placement of an orbital implant.

Histopathology revealed a chronic necrotizing/suppurative granulomatous inflammation involving the retina and optic nerve without retrolaminar extension (fig. 3). Inflammatory cells were identified extending into the optic nerve to the level of the lamina cribrosa. Special stains for acid-fast bacilli (Ziehl-Neelsen), fungi (Gomori methenamine silver), and other bacteria (Warthin-Starry) were all negative for organisms. The suppurative granulomatous inflammation was considered to be suggestive of Bartonella infection. Polymerase chain reaction testing on the histologic block using 16S rRNA gene and ribC primer sets did not detect Bartonella DNA.

The patient was subsequently referred to the pediatric infectious diseases clinic. Upon further questioning, a positive history of exposure to kittens was elucidated. Physical examination was significant for multiple healed and healing linear lesions on both arms and hands, consistent with recent kitten scratches. IgG titer for Bartonella henselae was positive at $>1: 1,024$. IgM titer for $B$. henselae was negative. A complete blood count, complete metabolic panel, and C-reactive protein done at the time of the infectious diseases referral revealed negative results. A Westergren sedimentation rate was mildly elevated at $17 \mathrm{~mm} / \mathrm{h}$.

Given the question of the possible residual inflammation and concerns about pineal gland inflammation, the patient was treated with trimethoprim-sulfamethoxazole and rifampin for 2 weeks with plans for reimaging. He tolerated the antibiotics well and remains asymptomatic. On the 6-week follow-up examination, the patient was healing well, the socket had no evidence of infection or inflammation and was advised to proceed with fitting of prosthesis. Repeat MRI revealed interval total resolution of enlarged pineal gland, likely denoting resolution of inflammatory changes (fig. 2b).

\section{Discussion}

Ocular involvement is relatively uncommon in cat scratch disease (CSD) but it can affect all layers of the eye. In the posterior segment, CSD has a wide spectrum of ophthalmic manifestations including: neuroretinitis, optic neuritis/papillitis, branch retinal arteriolar and venular occlusions, acute multifocal inner retinitis or retinal white dot syndrome, retinal vasculitis, retinitis, focal choroiditis or serous retinal detachment [3].

Optic nerve involvement in CSD is rare and has been referred to as peripapillary angiomatous lesion or optic disc granuloma. When present, it is associated with significant visual loss in the involved eye, anterior chamber and vitreous inflammation, white retinal infiltrates, neuroretinitis with a macular star, overlying vascular proliferation and exudative retinal detachment (table 1) [412].

Cat Scratch Disease: Expanded Spectrum
In our patient, no signs of overt inflammation were present on examination; the conjunctiva was white and quiet and the anterior chamber and vitreous were devoid of inflammatory cells. Moreover, there was no evidence of neuroretinitis or hard exudates on fundus exam. To our knowledge, this is the first description of the pathology of the optic nerve granuloma associated with CSD characterized by zonal granulomatous response surrounded by vascular proliferation that is similar to the Bartonella granuloma elsewhere in the body.

Pineal gland enlargement played a pivotal role in directing the management plan in this case. Studies on mammals have shown pinealitis in cases of active uveitis but the presence of such a relationship in humans has not been clearly elucidated [13]. Both the pineal gland and the retina express the $\mathrm{S}$-antigen in abundance and exposure to this immune-privileged antigen elicits experimental autoimmune uveitis in animal models [14]. In our case, there was a clear radiographic correlation between the presence of optic disc granuloma and pineal gland enlargement with interval resolution of the enhancement after antibiotic therapy.

In conclusion, optic nerve granuloma is a rare form of CSD and could clinically mimic retinoblastoma. Pineal gland enlargement (pinealitis) may be associated with CSD.

\section{Statement of Ethics}

The study complied with the guidelines for human studies and animal welfare regulations. The subject gave informed consent, and the study protocol was approved by the institute's committee on human research.

\section{Disclosure Statement}

The authors have no conflicts of interest to declare.

References

1 Kivela T: The epidemiological challenge of the most frequent eye cancer: retinoblastoma an issue of birth and death. Br J Ophthalmol 2009;93:1129-1131.

2 de Jong MC, Kors WA, de Graaf P, Castelijns JA, Kivela T, Moll AC: Trilateral retinoblastoma: a systematic review and meta-analysis. Lancet Oncol 2014;15:1157-1167.

3 Ormerod LD, Dailey JP: Ocular manifestations of cat-scratch disease. Curr Opin Ophthalmol 1999;10:209-216. 
4 Curi AL, Machado D, Heringer G, et al: Catscratch disease: ocular manifestations and visual outcome. Int Ophthalmol 2010;30:553558.

5 Fish RH, Hogan RN, Nightingale SD, Anand R: Peripapillary angiomatosis associated with cat-scratch neuroretinitis. Arch Ophthalmol 1992;110:323.

6 Ulrich GG, Waecker NJ Jr, Meister SJ, Peterson TJ, Hooper DG: Cat scratch disease associated with neuroretinitis in a 6-year-old girl. Ophthalmology 1992;99:246-249.

7 Cunningham ET Jr, McDonald HR, Schatz H, Johnson RN, Ai E, Grand MG: Inflammatory mass of the optic nerve head associated with systemic Bartonella henselae infection. Arch Ophthalmol 1997;115:1596-1597.
8 Kerrison JB, Bennett MD, Newman NJ, Phillips PH, Aaberg TM Sr: Atypical mass lesion associated with cat-scratch disease. Clin Infect Dis 1999;29:221-223.

9 Gray AV, Reed JB, Wendel RT, Morse LS: Bartonella henselae infection associated with peripapillary angioma, branch retinal artery occlusion, and severe vision loss. Am J Ophthalmol 1999;127:223-224.

10 Solley WA, Martin DF, Newman NJ, et al: Cat scratch disease: posterior segment manifestations. Ophthalmology 1999;106:1546-1553.
11 Matsuo T, Yamaoka A, Shiraga F, et al: Clinical and angiographic characteristics of retinal manifestations in cat scratch disease. Jpn J Ophthalmol 2000;44:182-186.

12 Ghazi NG, Sams WA: A case of cat-scratch disease with unusual ophthalmic manifestations. Middle East Afr J Ophthalmol 2012;19: 243-246.

13 Kalsow CM, Dwyer AE, Smith AW, Nifong TP: Pinealitis accompanying equine recurrent uveitis. Br J Ophthalmol 1993;77:46-48.

14 Breitman ML, Tsuda M, Usukura J, et al: Expression of S-antigen in retina, pineal gland, lens, and brain is directed by $5^{\prime}$-flanking sequences. J Biol Chem 1991;266:15505-15510. 